\title{
Collective factors drive individual invasive species control behaviors: evidence from private lands in Montana, USA
}

\author{
Alice A. Lubeck ${ }^{1}$, Alexander L. Metcalf ${ }^{1}$, Crystal L. Beckman ${ }^{2}$, Laurie Yung $^{3}$ and Justin W. Angle $^{4}$
}

\begin{abstract}
Invasive terrestrial plants globally threaten agricultural and natural systems. Prolific dispersal mechanisms enable "weeds" to colonize across ownership boundaries, constituting a collective action problem where effective control requires contributions from multiple actors. Researchers have long recognized the cross-boundary nature of weed control, yet most studies have focused on whether actor-specific characteristics, such as sociodemographics and cognition, influenced individual weed control behaviors. More recent work has begun to explore the drivers of communal control efforts, i.e., cooperatives, group actions. Few studies have empirically investigated how the collective aspects of weed invasions influence individual control behaviors. Here we provide quantitative evidence of a relationship between collective aspects of the weed control problem and landowners' willingness to engage in individual weed control efforts. In a mail-back survey of Montana landowners $(n=1327)$ we found collective factors, such as injunctive norms and the belief that weeds are a cross-boundary problem, were significantly correlated with willingness to engage in three different weed control behaviors. Each behavior was correlated with a unique suite of collective factors suggesting that successful interventions must be behavior-specific. These results add to a growing body of evidence that the collective nature of invasive species control is critical for understanding human behavioral responses.
\end{abstract}

Key Words: collective action; conservation; Montana; private lands; weed control

\section{INTRODUCTION}

The spread of invasive species is one of the leading drivers of global environmental change (Simberloff et al. 2013). In terrestrial systems, invasive plants (hereafter, "weeds"), whether native or exotic, outcompete endemic plants and alter ecosystems through adaptive strategies that allow rapid spread, challenging human efforts to control them (Baker 1974, Nackley et al. 2017, Zimdahl 2018). Weeds threaten global biodiversity (Parker et al. 1999) and have significant economic impact, especially in agricultural systems where their presence reduces quality, efficacy, and functionality in production (Sheley and Smith 2012). Once weeds have propagated, both natural and human-mediated processes can contribute to dispersal, often across jurisdictional and ownership boundaries (Baker 1974, Fiege 2005). Thus, in most systems, particularly those with complex ownership mosaics, effective weed control requires contributions from many actors. In landscapes where the individual decisions of private landowners aggregate to influence ecological outcomes over broad scales (Odum 1982), weed control becomes a collective action problem. In these social dilemmas, the behaviors of one actor affects others, creating negative externalities regardless of consent (Kollock 1998). To date, most research on weed control efforts has explored how actor-specific characteristics, such as sociodemographics and cognitions, influence individual weed control behaviors on private land (Sheley et al. 1996, Steele et al. 2006, Marshall et al. 2011, Fischer and Charnley 2012). More recent work has begun to explore the drivers of communal control efforts, i.e., cooperatives, group actions (Hershdorfer et al. 2007, Aslan et al. 2009, Reid et al. 2009, Marshall et al. 2016, Graham and Rogers 2017, McKieran 2017). Few studies have empirically investigated how the collective aspects of the problem influence individual weed control behaviors (Epanchin-Niell et al. 2010,
Minato et al.2010). To mitigate the threat weeds pose to important social and ecological systems around the world, it is critical to understand how landowners' individual behaviors are affected by the collective nature of the problem.

In collective action problems, human behaviors are driven by both individual and collective factors (Ostrom 1990, Chong 1991). Individual factors are characteristic specific to each actor, such as age, gender, financial resources, knowledge, physical ability, attitudes, and beliefs. In contrast, collective factors are those that derive from the collective nature of the problem, such as awareness of cross-boundary interrelationships, beliefs about normative behaviors or expectations, or confidence that collective efforts can achieve desired outcomes. Collective factors can be externally imposed on actors, such as social sanctions, or internally motivated, such as the desire to be a good neighbor. In many different contexts, research has demonstrated that human behaviors are often heavily influenced by collective factors (Ostrom 1990, Chong 1991, Finkel and Muller 1998). For example, game theory research has demonstrated that individuals alter behavior to maintain reputation and social standing (Chong 1991, Milinski et al. 2002, Nowak and Sigmund 2005), based on normative beliefs (Finkel and Muller 1998), or in response to faceto-face interactions with others (Ostrom 1990).

Despite the collective nature of weed control, most human dimensions research has focused on the individual factors that drive weed control behaviors (García-Llorente et al. 2008, Sheley et al. 2010, Selge et al. 2011). For example, researchers have found that attitudes toward specific species affect evaluations of acceptable management responses, and those unconcerned about weeds are less likely to control than others whose livelihoods are impacted by weeds or for whom biodiversity is a management

${ }^{1}$ Human Dimensions Lab, W.A. Franke College of Forestry and Conservation, University of Montana, ${ }^{2}$ Montana Department of Natural Resources and Conservation, ${ }^{3}$ W.A. Franke College of Forestry and Conservation, University of Montana, ${ }^{4}$ School of Business Administration, University of Montana 
goal (Marshall et al. 2011, Fischer and Charnley 2012). Frequent constraints to weed control behaviors include lack of time, money, and knowledge (Sheley et al. 2010, Yung et al. 2015). Many landowners do not know how weeds spread and are unable to correctly identify weed species (Aslan et al. 2009, Sheley et al. 2010, Fischer and Charnley 2012). However, across studies, many authors acknowledge the importance of cross-boundary or collective factors, even if they do not specifically incorporate these dimensions into models of individual behavior (Reid et al. 2009, Epanchin-Niell et al. 2010, Yung et al. 2015, Marshall et al. 2016, Niemiec et al. 2016). For instance, Yung et al. (2015) found that many landowners believed their weed control efforts were undermined by weed seeds dispersed from neighboring properties, and Niemiec et al. (2016) observed people who felt discouraged from controlling an invasive tree in Hawai' $i$ because they perceived a lack of participation or coordination among neighboring landowners. In other contexts, landowners did not trust that newer, amenity owners, i.e., those who move to rural areas for the lifestyle rather than to work the land, would implement effective control, thus undermining the efforts of more long-term landowners to control weeds (Yung and Belsky 2007, Klepeis et al. 2009, Graham 2013, Epanchin-Niell and Wilen 2015).

There is growing recognition that more work is needed to understand the collective aspects of weed control (Bagavathiannan et al. 2019, Graham et al. 2019), yet the developing literature is mostly qualitative, or focused on collective actions, such as those organized by collaborative weed groups, rather than on individual actions (Hershdorfer et al. 2007, Graham 2013, Marshall et al. 2016, Graham and Rogers 2017). Qualitative accounts of efforts to control weeds are useful for understanding unique contexts or developing broader hypotheses, yet do not allow for generalization on their own. So, although there is evidence suggesting some landowner control efforts are driven by a motivation to be good neighbors and the expectation that others will reciprocate (Yung and Belsky 2007, Klepeis et al. 2009, Yung et al. 2015, Niemiec et al. 2016, Marshall et al. 2016), or that some communities enforce weed control norms through social control mechanisms such as gossiping (Merry 1984, Minato et al. 2010), the degree to which these collective factors broadly influence weed control behaviors is unknown, especially after controlling for important individual factors. Similarly, although collective actions for weed control may be particularly effective, many control decisions are made by individual landowners in an individual context, i.e., treating their own land, not part of a cooperative effort. Collective responses to weed control have received increased attention in recent years, leaving understudied the role of collective factors in driving individual behaviors (Graham et al. 2019).

\section{Research purpose and questions}

With this study we sought to quantify the role of collective factors in determining landowners' individual weed control behaviors. We hypothesized that individual weed control on private lands is a collective action problem because, holding individual factors constant, collective factors would explain significant variation in individual landowner weed control behaviors. More specifically, for our application of the collective interest model (CIM) we drew independent variables from the extant qualitative weed control research and broader collective action literature, including the following: injunctive and descriptive normative beliefs (Nowak and Sigmund 2005, Yung and Belsky 2007, Marshall et al. 2016, McKiernan 2017), the recognition that weed control is a crossboundary problem (Fiege 2005, Marshall 2009, Yung et al. 2015), reciprocity (Kollock 1998, Ostrom 2000, Panchanathan and Boyd 2004, Marshall et al. 2016), area-wide satisfaction with weed management (Finkel and Muller 1998, Reid et al. 2009, Graham and Rogers 2017), sense of community (Graham and Rogers 2017), and group efficacy (Chong 1991, Finkel and Muller 1998, Epanchin-Niell et al. 2010). Previous literature has established the relationship between individual factors and individual weed control behaviors. Here, we extend this line of research by quantifying the additional variance in weed control behavior explained by collective factors. With this approach we provide a more complete understanding of individual landowners' utility calculus when choosing to control for weeds and offer insights for improving future research and outreach efforts seeking to explain or promote weed control on private lands.

\section{METHODS}

\section{Collective interest model}

To accomplish these research goals, we employed the collective interest model (CIM, Eqn. 1) to analyze landowner responses to a mail-back questionnaire. The CIM was first developed to explain political protest behavior and has since been used to investigate behaviors in a variety of collective action situations including environmental activism and collective housing behaviors (Finkel and Muller 1998, Lubell 2002, Yau 2011). The CIM allows associations between behaviors of interest and individual as well as collective factors, including (i) an individual's value of the public goods provided by the action, (ii) the extent to which an individual thinks their personal actions can affect the provisioning of the public good, i.e., individual efficacy, (iii) the extent to which an individual believes the group can successfully achieve their aim, i.e., group efficacy, and (iv) the costs and benefits of engaging in behavior, including financial, emotional, and cognitive costs, such as attitudes, norms, knowledge, values. Employing the CIM allowed us to combine individual factors that have been established in the weed control literature with collective factors to compare their relative importance to individual weed control behaviors (Finkel and Muller 1998). The CIM is conceptualized as.

$$
E V=\left[\left(p_{i}+p_{g}\right) * V\right]+B-C
$$

where $E V$ is the expected value of behavior, $p_{i}$ is individual efficacy, $p_{g}$ is group efficacy, $V$ is the value of the outcome of the collective behavior, $\mathrm{B}$ is the benefits of engaging in the behavior, and $\mathrm{C}$ is the costs of engaging in the behavior (Finkel et al. 1989).

The CIM was applied once before to investigate weed control, but with respect to collective rather than individual behaviors. Niemiec et al. (2016) used the CIM in a study from the Puna district of Hawai'i, where non-native albizia trees, Falcataria moluccana, were dropping branches after a hurricane, causing dramatic and costly damage to cars and homes. The CIM proved useful for explaining substantial variance in "activism" behaviors such as teaching a neighbor how to remove albizia or removing albizia from a public space (Niemiec et al. 2016). It remains unclear, however, if collective factors operationalized by these authors also explain variation in individual weed control 
behaviors, or if their effects are limited to collective behaviors related to this invasive tree.

\section{Study site}

The state of Montana, USA provided an ideal context to study landowners' weed control because weeds have long been a problem there and $60 \%$ of land is privately owned. Weeds were identified as a problem in the state as early as the 1890 s when homesteaders began to farm the area (Fiege 2005). Currently, Montana has 17 high priority noxious weed species that are prevalent in many counties, and 20 other, less abundant noxious weed species (Montana Department of Agriculture 2017). Montana invests in extensive outreach efforts to encourage landowners to control for weeds, including enforcement, landowner workshops, newsletters, billboards, and other marketing materials. A recent assessment estimated that invasive weeds cost the state of Montana well over $\$ 100$ million annually, with an additional $\$ 25$ to $\$ 50$ million invested in research, outreach, education, monitoring, and control (Creative Resource Strategies LLC 2016), significant investments for a state with only just over 1 million residents.

\section{Data collection}

We collected data for this study using a mail-back questionnaire sent to Montana private landowners (Appendix 1). Our sampling frame included nonpublic landowners owning between 0.2 and 2500 hectares of land outside of incorporated city limits. We focused on mid- and smaller sized parcels in these areas because our extension agent study partners, i.e., university staff/faculty who offer natural resource training programs, saw them as a particularly challenging group to motivate into weed control action. We regionally stratified the sample, i.e., western, central, and eastern regions (Fig. 1), to ensure adequate representation of landowners from across the state because population density in Montana is higher in the west and lower in the east. To address this sampling concern we established regions based on administrative boundaries used by state agencies that were familiar and meaningful to our practitioner study partners. We drew an initial sample of 4500 landowners ( 1500 per region) using the Montana cadastral data (Base Map Service Center Montana State Library, http://svc.mt.gov/msl/mtcadastral). We pretested the questionnaire with four university graduate students and faculty, four employees from a state natural resource agency, and three extension professionals. We administered the survey using a tailored design method (Dillman et al. 2014) that included a cover letter and questionnaire, a reminder postcard, and two replacement questionnaires to nonrespondents, with each mailing spaced approximately two weeks apart. All research methods were approved by our university's Institutional Review Board prior to administration.

\section{Adapted collective interest model}

In our adaption of the CIM we predicted that individuals would be more willing to engage in weed control if, (i) they believed their weed control actions would be successful, (ii) they believed those around them were also controlling, (iii) they believed control efforts by themselves and other landowners could provide benefits, (iv) they valued a weed free environment, and (v) if actions were not too costly, defined broadly to include financial, informational, and social costs and benefits. Below we describe how we operationalized each of these factors, including adaptation of extant measures from previous research on collective action problems (Finkel and Muller 1998, Lubell et al. 2007, Niemiec et al. 2016), and novel metrics.

Fig. 1. Map of Montana with the three regions, Western, Central and Eastern, used in survey implementation. Areas shown in green are public lands.

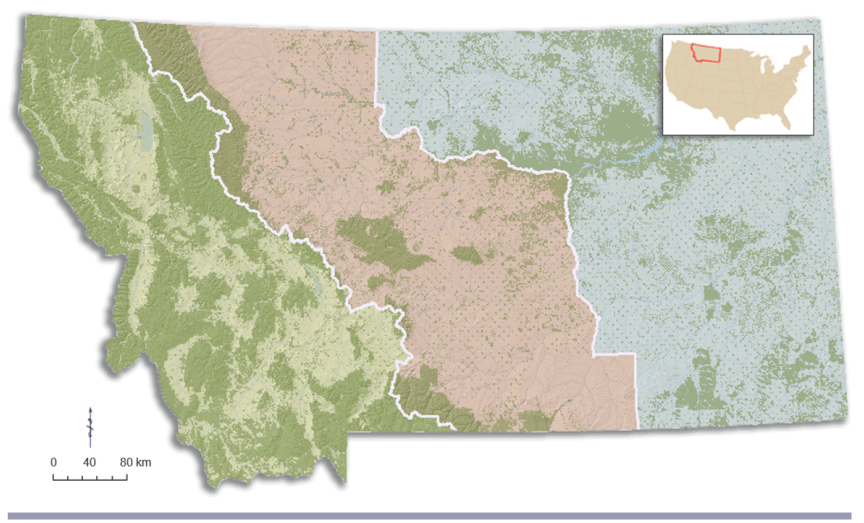

Dependent variables

We tested the model using four dependent variables: willingness to (i) work with an extension professional to develop a weed control plan, (ii) use herbicides to control weeds, (iii) release biocontrol, i.e., insects, to control weeds, and (iv) spend time pulling weeds on your property (Table 1). We conceptualized willingness as a behavioral intention, a precursor to behavior (Ajzen and Fishbein 2005). We chose these behavioral intentions as dependent variables because we were unable to independently observe actual behaviors, and self-reported weed control behaviors may be particularly problematic in Montana because landowners in the state are legally responsible for controlling noxious weeds (MCA Section 7-22-2116) which might lead to overstatements. Each dependent variable was measured on a fivepoint Likert scale from "very unwilling" to "very willing" (Table 1).

\section{Independent variables}

We drew independent variables from literature pertaining to invasive species control on private land, and other collective action research. Each independent variable was classified as an "individual" or "collective" factor, and measured on a five-point Likert-scale with unique anchors, with the exception of the descriptive norm, the injunctive norm, and network centrality variables, which were measured on dichotomous "yes/no" scales (Table 1)

\section{Individual factors}

We included several individual factors as covariates in the model that past research has found related to landowners' decisions to control weeds. Personal efficacy $\left(\mathrm{p}_{\mathrm{i}}\right)$, measured whether an individual believed their actions would contribute to the collective outcome. To measure $\mathrm{p}_{\mathrm{i}}$, we asked landowners if they felt their personal actions could help control for weeds on their property (Table 1, adapted from Niemiec et al. 2016). We measured individuals' valuation of the individual benefit, a weed-free environment $(\mathrm{V})$, by asking landowners to rate their level of concern about weeds affecting various aspects of their property (Table 1). 
Table 1. Constructs and descriptive statistics for the survey organized using the collective interest model.

\begin{tabular}{|c|c|c|c|c|c|c|}
\hline & & $\begin{array}{c}\text { CIM } \\
\text { designation } \\
\end{array}$ & Scale & Mean & $\begin{array}{l}\text { Standard } \\
\text { Deviation }\end{array}$ & $\begin{array}{l}\text { Cronbach's } \\
\text { Alpha }\end{array}$ \\
\hline \multicolumn{7}{|l|}{ Dependent $^{\dagger}$} \\
\hline & $\begin{array}{l}\text { Work with an extension professional to } \\
\text { develop a weed control plan for your } \\
\text { property }\end{array}$ & EV & $\begin{array}{l}\text { 5-point Very unwilling-Very } \\
\text { willing }\end{array}$ & 3.72 & 0.926 & \\
\hline & Use herbicides to control weeds & EV & $\begin{array}{l}\text { 5-point Very unwilling-Very } \\
\text { willing }\end{array}$ & 3.95 & 0.991 & \\
\hline & $\begin{array}{l}\text { Release biocontrol (insects) to control } \\
\text { weeds }\end{array}$ & EV & $\begin{array}{l}\text { 5-point Very unwilling-Very } \\
\text { willing }\end{array}$ & 3.73 & 1.01 & \\
\hline & $\begin{array}{l}\text { Spend time pulling weeds from your } \\
\text { property }\end{array}$ & EV & $\begin{array}{l}\text { 5-point Very unwilling-Very } \\
\text { willing }\end{array}$ & 3.83 & 0.992 & \\
\hline \multicolumn{7}{|l|}{$\begin{array}{l}\text { Independent: } \\
\text { Collective }\end{array}$} \\
\hline & Cross-boundary belief & $\mathrm{P}_{\mathrm{g}}$ & $\begin{array}{l}\text { 5-point Strongly disagree- } \\
\text { Strongly agree }\end{array}$ & 4.12 & 0.781 & \\
\hline & Reciprocity-notice or hear & $P_{g}$ & $\begin{array}{l}\text { 5-point Strongly disagree- } \\
\text { Strongly agree }\end{array}$ & 3.36 & 0.968 & \\
\hline & Reciprocity-motivate to act & $\mathrm{P}_{\mathrm{g}}$ & $\begin{array}{l}\text { 5-point Strongly disagree- } \\
\text { Strongly agree }\end{array}$ & 3.03 & 0.99 & \\
\hline & Generalized group efficacy & $\mathrm{P}_{\mathrm{g}}$ & $\begin{array}{l}\text { 5-point Strongly disagree- } \\
\text { Strongly agree }\end{array}$ & 3.85 & 0.884 & \\
\hline & Area wide satisfaction & $P_{g}$ & $\begin{array}{l}\text { 5-point Very unsatisfied-- } \\
\text { Very satisfied }\end{array}$ & 2.98 & 0.983 & \\
\hline & Network centrality-ask opinion & $\mathrm{C} / \mathrm{B}$ & Dichotomous $\mathrm{Y} / \mathrm{N}$ & 1.28 & 0.449 & \\
\hline & Network centrality-influence opinion & $\mathrm{C} / \mathrm{B}$ & Dichotomous $\mathrm{Y} / \mathrm{N}$ & 1.27 & 0.445 & \\
\hline & Descriptive norm & $\mathrm{C} / \mathrm{B}$ & Dichotomous $\mathrm{Y} / \mathrm{N}$ & 1.44 & 0.497 & \\
\hline & Injunctive norm & $\mathrm{C} / \mathrm{B}$ & Dichotomous Y/N & 1.54 & 0.499 & \\
\hline & Sense of Community & $\mathrm{C} / \mathrm{B}$ & & 3.93 & 0.830 & \\
\hline & $\begin{array}{l}\text { Sense of Community 1-"Strong sense of } \\
\text { community" }\end{array}$ & $\mathrm{C} / \mathrm{B}$ & $\begin{array}{l}\text { 5-point Strongly disagree- } \\
\text { Strongly agree }\end{array}$ & 3.52 & 0.932 & .843 \\
\hline & $\begin{array}{l}\text { Sense of Community 2-"People can solve } \\
\text { area problems" }\end{array}$ & $\mathrm{C} / \mathrm{B}$ & $\begin{array}{l}5 \text {-point Strongly disagree- } \\
\text { Strongly agree }\end{array}$ & 3.47 & 0.913 & \\
\hline & $\begin{array}{l}\text { Sense of Community 3-"I have influence } \\
\text { over the community" }\end{array}$ & $\mathrm{C} / \mathrm{B}$ & $\begin{array}{l}\text { 5-point Strongly disagree- } \\
\text { Strongly agree }\end{array}$ & 3.16 & 0.953 & \\
\hline & $\begin{array}{l}\text { Sense of Community } 4 \text {-"I take an active } \\
\text { role in solving area problems" }\end{array}$ & $\mathrm{C} / \mathrm{B}$ & $\begin{array}{l}\text { 5-point Strongly disagree- } \\
\text { Strongly agree }\end{array}$ & 3.20 & 0.926 & \\
\hline \multicolumn{7}{|l|}{$\begin{array}{l}\text { Independent: } \\
\text { Individual }\end{array}$} \\
\hline & Personal efficacy & $P_{i}$ & $\begin{array}{l}\text { 5-point Strongly disagree- } \\
\text { Strongly agree }\end{array}$ & 4.11 & 0.773 & \\
\hline & Concern about private property & $\mathrm{V}$ & & 3.93 & 0.83 & \\
\hline & Concern 1-"Enjoyment" & $\mathrm{V}$ & $\begin{array}{l}\text { 5-point Strongly disagree- } \\
\text { Strongly agree }\end{array}$ & 4.09 & 0.903 & .907 \\
\hline & Concern 2-"Economic Value" & $\mathrm{V}$ & $\begin{array}{l}\text { 5-point Strongly disagree- } \\
\text { Strongly agree }\end{array}$ & 4.03 & 0.909 & \\
\hline & Concern 3-"Productivity" & V & $\begin{array}{l}\text { 5-point Strongly disagree- } \\
\text { Strongly agree }\end{array}$ & 3.91 & 0.994 & \\
\hline & Concern 4-"Aesthesis" & V & $\begin{array}{l}\text { 5-point Strongly disagree- } \\
\text { Strongly agree }\end{array}$ & 3.46 & 0.896 & \\
\hline & Concern 5-"Ability to Use" & V & $\begin{array}{l}\text { 5-point Strongly disagree- } \\
\text { Strongly agree }\end{array}$ & 3.46 & 1.11 & \\
\hline & Money & $\mathrm{C} / \mathrm{B}$ & $\begin{array}{l}\text { 5-point Strongly disagree- } \\
\text { Strongly agree }\end{array}$ & 3.28 & 1.12 & \\
\hline & Time & $\mathrm{C} / \mathrm{B}$ & $\begin{array}{l}\text { 5-point Strongly disagree- } \\
\text { Strongly agree }\end{array}$ & 3.18 & 1.12 & \\
\hline & Confidence in ability to identity weeds & $\mathrm{C} / \mathrm{B}$ & $\begin{array}{l}\text { 5-point Strongly disagree- } \\
\text { Strongly agree }\end{array}$ & 3.48 & 1.09 & \\
\hline & Confidence in ability to control & $\mathrm{C} / \mathrm{B}$ & $\begin{array}{l}\text { 5-point Strongly disagree- } \\
\text { Strongly agree }\end{array}$ & 3.43 & 1.08 & \\
\hline & Trust the government to control for weeds & $\mathrm{C} / \mathrm{B}$ & $\begin{array}{l}5 \text {-point Strongly disagree- } \\
\text { Strongly agree }\end{array}$ & 2.17 & 0.958 & \\
\hline
\end{tabular}




\begin{tabular}{|c|c|c|c|c|}
\hline Age & $\mathrm{C} / \mathrm{B}$ & Open response & 64.32 & 12.88 \\
\hline Biocentric environmental belief & $\mathrm{C} / \mathrm{B}$ & $\begin{array}{l}\text { 5-point Strongly disagree- } \\
\text { Strongly agree }\end{array}$ & 3.77 & 1.02 \\
\hline Anthropocentric environmental belief & $\mathrm{C} / \mathrm{B}$ & $\begin{array}{l}\text { 5-point Strongly disagree- } \\
\text { Strongly agree }\end{array}$ & 2.25 & 1.05 \\
\hline Education & $\mathrm{C} / \mathrm{B}$ & $\begin{array}{l}5 \text { Categories: Grade school, } \\
\text { High school/GED, Some } \\
\text { college, College graduate, } \\
\text { Post graduate }\end{array}$ & \multicolumn{2}{|c|}{ Mode $=$ Some College } \\
\hline Income & $\mathrm{C} / \mathrm{B}$ & $\begin{array}{l}9 \text { Categories: }>\$ 9999, \\
\$ 10,000-\$ 19,999, \$ 20,000- \\
\$ 39,999, \$ 40,000-\$ 59,999, \\
\$ 60,000-\$ 79,999, \$ 80,000- \\
\$ 99,999, \$ 100,000-\$ 119,999, \\
\$ 120,000-\$ 139,999,> \\
\$ 140,000\end{array}$ & \multicolumn{2}{|c|}{ Mode $=\$ 60,000-\$ 79,000$} \\
\hline Acreage & $\mathrm{C} / \mathrm{B}$ & Open response & \multicolumn{2}{|c|}{ Median $=20$} \\
\hline Gender & $\mathrm{C} / \mathrm{B}$ & Male/ Female & \multicolumn{2}{|c|}{$\begin{array}{l}\text { Male } 63.5 \% \\
\text { Female } 28.8 \%\end{array}$} \\
\hline
\end{tabular}

Engaging in weed control may require material resources $(C)$ and/ or provide social and psychological benefits (B; Yung et al. 2015). We used sociodemographic information provided by respondents to determine how easily they could afford the costs (C) of completing control behavior. These included age, income, education level, acreage, and gender (adapted from Lubell et al. 2007 and Niemiec et al. 2016). To measure the psychological benefits of engaging in weed control we measured biocentric and anthropocentric environmental beliefs using scales from the new environmental paradigm (Dunlap and Van Liere 1978).

\section{Collective factors}

We included in the model several collective factors predicted to explain variance in weed control behavior (Table 1). We conceptualized group efficacy $\left(\mathrm{p}_{\mathrm{g}}\right)$ as a combination of whether an individual believed that weed control was a collective problem, that landowners in their area could be successful controlling for weeds, that those around them were controlling for weeds or could be inspired to control, and that current weed control efforts in their area were satisfactory (adapted from Niemiec et al. 2016). To measure if a landowner believed that others around them were contributing, we asked landowners if they felt most people in their area were controlling for weeds. To measure if a landowner believed that others could be inspired to control for weeds, we asked landowners if other landowners would notice their weed control efforts, and if their weed control efforts would inspire others to reciprocate. To evaluate a landowner's perception of weed control on lands near their property, we asked if they were satisfied with weed control in their general area.

To measure the costs and benefits $(\mathrm{C} / \mathrm{B})$ that landowners might incur from weed control, monetary and otherwise, we included several additional questions (Table 1). To start, we asked respondents if they believed they had enough (i) time, (ii) money, and (iii) knowhow (including identifying weeds and knowing how to control them). We also included a measure of (iv) injunctive and (v) descriptive norms regarding weed control to measure the potential social benefits or sanctions of engaging in weed control (Klepeis et al. 2009, Niemiec et al. 2016). Additionally, we measured (vi) network centrality for each landowner (adapted from Lubell et al. 2007), assuming the more people landowners communicated with about weeds, the lower their costs of acquiring information necessary for control. Communication about a collective problem has been shown to encourage collaborative behaviors by those involved in the collective problem (Janssen 2013). We included a (vii) "sense of community" scale, which used four items to measure if a landowner felt supported by their community, and whether or not they were an effective agent in their community (adapted from Absher et al. 2013). Like network centrality, we posited that if an individual was generally an active member of the community they would have a lower cost of obtaining help or receiving information about weed control (Graham and Rogers 2017).

Prior to analysis, we created two composite variables from these independent variable items: (i) "concern" was calculated as the mean response across five items measuring different ways weeds might negatively affect landowners' properties, and (ii) "sense of community" was calculated as the mean response across four items regarding community effectiveness in solving problems, and to what degree landowners felt they could be effective agents in their community (Absher et al. 2013). We measured scale reliability of these two composite independent variables using Cronbach's alpha test with a 0.65 cut-off (Vaske 2008; Table 1).

\section{Analysis}

To test our hypotheses we conducted an ordinary least squares (OLS) regression for each of our dependent variables, a common approach to CIM analyses (Lubell et al. 2007, Yau 2011, Niemiec et al. 2016). The linear additive function form of OLS regression does not represent the multiplicative relationships in the CIM so the equation is often adiusted to.

$$
E V(\text { weed controlbehaviors })=p_{i}+p_{g}+V+B-C
$$

which allows for the simplest interpretation of significant variables (Lubell et al. 2007). In some cases this adaption of the CIM may increase the relative importance of benefits and costs because there is no amplifying effect between personal and group efficacy and the value of the outcome. To test OLS assumptions 
we reviewed descriptive statistics of each variable to confirm normality, linear relationships with dependent variables, and homoscedasticity. We used variance of inflation factor (VIF) procedures to determine there was no multicollinearity, and P-P plots to determine if residuals were normally distributed (Vaske 2008). To account for sampling design, we weighted responses by region (Vaske 2008). We performed all analyses using IBM SPSS Statistics 24 .

As a nonresponse check, we conducted independent t-tests comparing respondents to nonrespondents across several variables available in the Montana cadastral dataset, including land value, total value, building value, total property size, and hectares of land in farm, grazing, forest, fallow, irrigated, wild hay, and nonquality, i.e., unsuitable for farming. We used a $p$ value of 0.05 to detect significant differences between respondents and nonrespondents.

\section{RESULTS}

The initial sample size was reduced to 4424 after we removed duplicate and incorrect addresses. Respondents totaled 1327 for a response rate of $30 \%$. Respondents were generally well educated with $51 \%$ of landowners having a college degree or higher, older with an average age of 64 years, $69 \%$ male, and of higher incomes with $34 \%$ earning over $\$ 100,000$ of annual household income. This sociodemographic profile is generally consistent with landowner populations across the U.S. Although we included region as a covariate in our analyses, it was never significant and thus excluded from presentation here. Descriptive statistics for all variables are shown in Table 1, with values weighted to represent statewide inference to our sampling frame.

Residual plots indicated normal distributions for three of the dependent variables. However, using the P-P plot we determined that data for the dependent variable "willingness to pull weeds on your property" had non-normally distributed residuals and thus excluded this measure from further analysis. We determined there was no multicollinearity using VIF procedures. We found no differences between respondents and nonrespondents in our sample with two minor exceptions: respondents had slightly more hectares of wild hay $(p=0.004)$ and nonquality land $(p=0.019)$. Respondents owned an average of 0.99 ha of wild hay and 1.15 ha of nonquality land, while nonrespondents had an average of 0.68 ha of wild hay and 1.36 ha nonquality land. Across all other variables, respondents were not significantly different from nonrespondents. Given these small differences, we proceeded with the assumption our respondents were representative of the broader population defined by our sampling frame.

The majority of landowners agreed or strongly agreed that weeds decreased their enjoyment of their property $(82 \%)$, and that weeds limited their ability to use their property in the ways they wanted (81\%). Although most landowners were concerned about weeds, many reported limited resources for control efforts. For example, only about half felt they had enough time $(50 \%)$ or money $(53 \%)$ to control for weeds on their property.

\section{Weed control behaviors}

We found collective factors were significant for each behavior, although each dependent variable generated unique results (Table 2). Three collective measures were significant and positively correlated with "willingness to work with an extension professional": the belief that weed control was a collective problem, group efficacy, and sense of community. Three individual beliefs were also significant and negatively correlated with this dependent variable: having enough money, confidence in weed control ability, and the anthropocentric environmental belief. Income was the only individual variable positively correlated with this dependent variable, and it was the strongest predictor (Table 2). Two collective measures were significant and positively correlated with "willingness to use herbicides": the belief that weed control was a collective problem, and the injunctive social norm. Two individual factors were significant and negatively correlated with this dependent variable: concern about weeds, and the biocentric environmental belief. Income was once again positively correlated and also the strongest predictor of this behavioral intention (Table 2). Network centrality was the sole collective factor that was significantly and positively correlated with "willingness to release biocontrol." Two individual factors were significantly positively correlated with this dependent variable: concern about weeds, and education. Two individual factors were significant yet negatively correlated: having enough money, and the anthropocentric environmental belief (Table 2).

\section{DISCUSSION}

Here we employed a quantitative model to investigate the relationship between collective factors and independent weed control behaviors on private lands. Our results indicated that collective factors were significantly related to individuals' willingness to take individual action to control for weeds on their properties. Collective factors were correlated with each weed control behavior, suggesting their importance across a variety of weed control interventions. The significance of collective factors, even across our large study site and broad context of weed control, e.g., species and situationally generic, and with a broad array of individual factors accounted for, show they are essential for understanding landowner weed control decisions and may provide useful insight for those attempting to encourage more robust control measures on private lands.

Our results corroborate what has been established in political science and game theory research, but has been previously overlooked in the weed control literature: individuals making seemingly autonomous decisions are influenced by the collective nature of the problems they encounter (Schelling 1971, Chong 1991, Kollock 1998, Ostrom 2000, Milinski et al. 2002). In Montana at least, the factors motivating landowners to control for weeds mirror the motivations for others to engage in a variety of collective action problems. Specifically, landowners' behaviors were correlated with injunctive normative beliefs, important motivators for political activism participation (Chong 1991), reciprocity, an important factor leading to cooperation in economic games (Milinski et al. 2002), as well as environmental activism (Lubell et al. 2006), and network centrality, which has enabled residents in other settings to engage in recycling programs (Everett and Peirce 1991). This adds an important dimension to the growing body of literature recognizing the collective dynamics relevant to invasive species management, but which has focused more on coordinated responses rather than individual behaviors (Graham et al. 2019). Natural resource research and practice would benefit by more deliberately engaging with collective action research from across disciplines to understand how collective 
Table 2. Selected independent variable from the collective interest model predicting willingness to engage in invasive species control behaviors, based on ordinary least squares (OLS) regression models.

\begin{tabular}{|c|c|c|c|c|c|c|c|c|c|c|}
\hline \multirow{3}{*}{\multicolumn{2}{|c|}{ Independent Variables }} & \multicolumn{9}{|c|}{ Dependent Variables } \\
\hline & & \multicolumn{3}{|c|}{$\begin{array}{c}\text { Work with an Extension } \\
\text { Professional to make a plan } \\
\mathrm{R}^{2}=0.201\end{array}$} & \multicolumn{3}{|c|}{$\begin{array}{l}\text { Use Herbicides } \\
\mathrm{R}^{2}=0.248 \\
\end{array}$} & \multicolumn{3}{|c|}{$\begin{array}{l}\text { Use Biocontrol } \\
\mathrm{R}^{2}=0.197 \\
\end{array}$} \\
\hline & & $\beta^{\dagger}$ & S.E. & $\mathrm{p}$ & $\beta$ & S.E. & $\mathrm{p}$ & $\beta$ & S.E. & $\mathrm{p}$ \\
\hline \multirow{6}{*}{ Collective } & Constant & 2.463 & 0.513 & 0.000 & 0.747 & 0.502 & 0.138 & 1.36 & 0.532 & 0.011 \\
\hline & Cross-boundary belief & 0.277 & 0.081 & 0.001 & 0.281 & 0.08 & 0.00 & 0.077 & 0.084 & 0.365 \\
\hline & Generalized Group efficacy & 0.116 & 0.067 & 0.083 & 0.046 & 0.065 & 0.479 & 0.036 & 0.069 & 0.604 \\
\hline & Sense of Community & 0.118 & 0.068 & 0.086 & 0.176 & 0.067 & 0.009 & 0.100 & 0.071 & 0.157 \\
\hline & Reciprocity-motivate to act & 0.04 & 0.116 & 0.523 & -0.001 & 0.061 & 0.985 & 0.111 & 0.065 & 0.089 \\
\hline & $\begin{array}{l}\text { Network centrality-ask your } \\
\text { opinion }\end{array}$ & -0.012 & 0.118 & 0.919 & 0.077 & 0.112 & 0.494 & 0.276 & 0.118 & 0.02 \\
\hline \multirow{8}{*}{ Individual } & Injunctive norm & 0.17 & 0.104 & 0.100 & 0.178 & 0.062 & 0.08 & 0.044 & 0.107 & 0.678 \\
\hline & $\begin{array}{l}\text { Anthropocentric } \\
\text { environmental belief }\end{array}$ & -0.086 & 0.049 & 0.084 & 0.069 & 0.157 & 0.157 & -0.108 & 0.051 & 0.034 \\
\hline & $\begin{array}{l}\text { Biocentric environmental } \\
\text { belief }\end{array}$ & 0.007 & 0.892 & 0.892 & -0.103 & 0.05 & 0.038 & 0.04 & 0.052 & 0.441 \\
\hline & Concern & 0.029 & 0.052 & 0.639 & 0.169 & 0.061 & 0.006 & 0.233 & 0.065 & 0.00 \\
\hline & Education & 0.048 & 0.045 & 0.282 & -0.018 & 0.044 & 0.689 & 0.117 & 0.046 & 0.012 \\
\hline & Money & -0.111 & 0.054 & 0.041 & 0.006 & 0.053 & 0.917 & -0.129 & 0.056 & 0.021 \\
\hline & $\begin{array}{l}\text { Confidence in ability to } \\
\text { control }\end{array}$ & -0.163 & 0.063 & 0.011 & 0.017 & 0.062 & 0.787 & -0.052 & 0.066 & 0.426 \\
\hline & Income & 0.326 & 0.171 & 0.056 & 0.369 & 0.167 & .023 & -0.055 & 0.176 & 0.755 \\
\hline
\end{tabular}

${ }^{\dagger}$ Coefficients are unstandardized.

factors influence individual's land management decisions, and how to better design interventions to motivate contributions to the public good of weed control.

Although collective factors were significantly correlated to each weed control behavior, relevant factors varied among behaviors, suggesting a need for outreach to be behaviorally specific. Take for example, "willingness to work with an extension agent," which was positively correlated with group efficacy, sense of community, and reciprocity. This finding suggests that landowners who saw themselves in a community that takes action to control weeds, and solve other problems, were more willing to seek professional assistance toward weed control. In contrast, the significance of injunctive normative beliefs to landowner "willingness to use herbicides" suggests this particular behavior could be promoted by elevating the belief that neighbors expected each other to control for weeds. Clearly, weed control behaviors are viewed distinctly by Montana landowners because each behavior was correlated with different factors. This has important implications for outreach and intervention programs, because those seeking to inspire increased control must understand that each behavior may require unique intervention strategies.

Individual factors were also correlated with unique behaviors, further emphasizing the need to tailor messaging to each behavior. For example, education was only significantly related to "willingness to release biocontrol," possibly reflecting that unique knowledge was needed to understand, implement, or accept biocontrol. Individuals' values were also correlated with unique behaviors, for instance, those with higher anthropocentric environmental beliefs were less "willing to work with an extension professional" and "release biocontrol." These results are consistent with others' findings, such as Selinske et al. (2016) who found that environmental beliefs influenced private landowners' decisions to engage in conservation initiatives. Taken together, these results underscore the conclusion that the most impactful outreach is oriented toward specific behaviors of interest and tailors messaging to induce such change (McKenzie-Mohr 2011, Amel et al. 2017). Importantly, however, messages promoting certain collective factors, such as emphasizing social normative beliefs, may motivate some, but not all, landowners to control weeds. Multiple pathways toward behavior change are needed as landowners and other audiences hold diverse motivations and constraints.

Concern about weeds was high across our sample suggesting weed campaigns that seek to increase concern may affect little behavior change (Amel et al. 2017). Rather than adding to the tens of millions spent toward raising awareness, a more effective approach might be to emphasize collective aspects of this issue, even using the same communication modes (McKenzie-Mohr et al. 2012). Billboards that celebrate control efforts by local landowners could serve to elevate both injunctive and descriptive norms around weed control. Praising participating landowners may be particularly effective because maintaining a positive reputation is a strong motivator toward cooperative behavior (Milinski et al. 2002). Collective factors could also be reinforced via multiple outreach channels such as face-to-face workshops that teach landowners control methods while reinforcing social norms surrounding weed control, reminding people about the cross-boundary nature of weeds, and inspiring increased trust and reciprocity among landowners and practitioners. Research has long shown that such interactions elevate the general, positive effect on cooperative behaviors (Ostrom 1990). 
In Montana, and perhaps elsewhere, there is profound opportunity for outreach professionals to inspire weed control by engaging landowners around the collective nature of the weed problem. Incorporating collective messages into weed control outreach could reframe weed control as a moral good for the community, which may inspire landowners who currently see the problem as unsolvable to rethink their calculus, although further experimental research is needed. In this way, our results set the stage for randomized, controlled outreach experiments testing the effectiveness of collective factors for inspiring increased weed control, and opening the door to a host of novel weed control outreach methods.

Although our study illuminates the importance of collective factors in weed control, our results are limited by our crosssectional design, which allowed us to correlate weed control with collective factors, but not determine causality. Application of these results to any specific weed species should be done with caution because some species can be viewed as beneficial (Marshall et al. 2011) while others as particularly harmful (Selge et al. 2011). Because of limited resources we were not able to conduct a more robust nonresponse check, so it remains possible that our respondents may be more apt to participate in collective action than nonrespondents. Our sample also consisted of a subset of Montana landowners based on land holding size and location who have unique perspectives on weed control that might not generalize to other landowners in the state, or elsewhere.

Overall, it remains clear that communication strategies seeking to inspire conservation behaviors on private land must be deliberate and evidence based (Urgeson et al. 2013, Amel et al. 2017, Drescher and Brenner 2018). Private landowners make many land management decisions autonomously, but they are clearly influenced by the behaviors and beliefs of those around them (Cialdini 2005, Amel et al. 2017). Conservation and stewardship efforts that consider the collective along with individual drivers of these decisions will better establish coordinated weed control efforts across ownership boundaries. These lessons likely apply not only to weeds, but extend to other private land conservation issues with collective dynamics such as wildlife habitat, watershed health, public access, and wildfire mitigation actions. Landowners ultimately make individual decisions to address even cross boundary problems, yet it is becoming increasingly clear that collective variables play a significant role in determining those choices.

Responses to this article can be read online at: http://www.ecologyandsociety.org/issues/responses. php/10897

\section{Acknowledgments:}

Foremost, we thank the landowners who took the time to complete our survey. We would also like to thank B. Christiaens and the Missoula County Extension and Weed District for funding the survey and providing valuable insight. We are grateful for the input from our partnering agencies and thank members of the Human Dimensions Lab at the University of Montana for comments on our survey and manuscript drafts. Additional funding was provided by
Defenders of Wildlife, Gallatin Valley Land Trust, Montana Department of Natural Resources and Conservation, Montana Noxious Weed Education Campaign, Montana State University Extension, Montana Wildlife and Parks, and the W.A. Franke College of Forestry and Conservation at the University of Montana.

\section{LITERATURE CITED}

Absher, J. D., J. J. Vaske, and K. M. Lyon. 2013. Overcoming barriers to firewise actions by residents. A report to Joint Fire Science Program. U.S. Forest Service, Pacific Southwest Research Station, St. Albany, California, USA.

Ajzen, I., and M. Fishbein. 2005. The influence of attitudes on behavior. Pages 173-221 in D. Albarracin, B.T. Johons, and M. P. Zanna, editors. The handbook of attitudes. Psychology Press, New York, New York, USA.

Amel, E., C. Manning, B. Scott, and S. Koger. 2017. Beyond the roots of human inaction: fostering collective effort toward ecosystem conservation. Science 356(6335):275-279. https://doi. org/10.1126/science.aal1931

Aslan, C. E., M. B. Hufford, R. S. Epanchin-Niell, J. D. Port, J. P. Sexton, and T. M. Waring. 2009. Practical challenges in private stewardship of rangeland ecosystems: yellow starthistle control in Sierra Nevadan foothills. Rangeland Ecology and Management 62(1):28-37. https://doi.org/10.2111/07-123

Bagavathiannan, M. V., S. Graham, Z. Ma, J. N. Barney, S. R. Coutts, A. L. Caicedo, R. De Clerck-Floate, N. M. West, L. Blank, A. L. Metcalf, M. Lacoste, C. R. Moreno, J. A. Evans, I. Burke, and H. Beckie. 2019. Considering weed management as a social dilemma bridges individual and collective interests. Nature Plants 5:343-351. https://doi.org/10.1038/s41477-019-0395-y

Baker, H. G. 1974. The evolution of weeds. Annual Review of Ecology and Systematics 5:1-24. https://doi.org/10.1146/annurev. es.05.110174.000245

Cialdini, R. B. 2005. Basic social influence is underestimated. Psychological Inquiry 16(4):158-161. https://doi.org/10.1207/ s15327965pli1604_03

Chong, D. 1991. Collective action and the civil rights movement. University of Chicago Press, Chicago, Illinois, USA.

Creative Resource Strategies LLC. 2016. Montana management assessment of invasive species. Montana Invasive Species Advisory Council, Helena, Montana, USA. [online] URL: http://dnrc.mt. gov/divisions/cardd/docs/misac-docs/montanastatewideassessmentfinal. pdf

Dillman, D. A. J. D. Smyth, and L. M. Christian. 2014. Internet: the tailored design method. Wiley, Hoboken, New Jersey, USA.

Drescher, M., and J. C. Brenner. 2018. The practice and promise of private land conservation. Ecology and Society 23(2):3. https:// doi.org/10.5751/ES-10020-230203

Dunlap, R. E., and Van Liere, K. D. 1978. The "new environmental paradigm." Journal of Environmental Education 9 (4):10-19.

Epanchin-Niell, R. S., M. B. Hufford, C. E. Aslan, J. P. Sexton, J. D. Port, and T. M. Waring. 2010. Controlling invasive species 
in complex social landscapes. Frontiers in Ecology and the Environment 8(4):210-216. https://doi.org/10.1890/090029

Epanchin-Niell, R. S., and J. E. Wilen. 2015. Individual and cooperative management of invasive species in human-mediated landscapes. American Journal of Agricultural Economics 97 (1):180-198. https://doi.org/10.1093/ajae/aau058

Everett, J. W., and J. J. Peirce. 1991. Social networks, socioeconomic status, and environmental collective action: residential curbside block leader recycling. Journal of Environmental Systems 21(1):65-84. https://doi.org/10.2190/ KMEJ-1P0D-6TCB-GG0T

Fiege, M. 2005. The weedy west: Mobile nature, boundaries, and common space in the Montana landscape. Western Historic Quarterly 36(1):22-47. https://doi.org/10.2307/25443100

Finkel, S. E., and E. N. Muller. 1998. Rational choice and the dynamics of collective political action: evaluating alternative models with panel data. American Political Science Review 92 (1):37-49. https://doi.org/10.2307/2585927

Finkel, S. E., E. N. Muller, and K. D. Opp. 1989. Personal influence, collective rationality, and mass political action. American Political Science Review 83(3):885-903. https://doi. org/10.2307/1962065

Fischer, A. P., and S. Charnley. 2012. Private forest owners and invasive plants: risk perception and management. Invasive Plant Science and Management 5(3):375-389. https://doi.org/10.1614/ IPSM-D-12-00005.1

García-Llorente, M., B. Martín-López, J. A. González, P. Alcorlo, and C. Montes. 2008. Social perceptions of the impacts and benefits of invasive alien species: implications for management. Biological Conservation 141(12):2969-2983. https://doi.org/10.1016/ j.biocon.2008.09.003

Graham, S. 2013. Three cooperative pathways to solving a collective weed management problem. Australasian Journal of Environmental Management 20(2):116-129. https://doi. org/10.1080/14486563.2013.774681

Graham, S., A. L. Metcalf, N. Gill, R. Niemiec, C. Moreno, T. Bach, V. Ikutegbe, L. Hallstrom, Z. Ma, and A. Lubeck. 2019. Opportunities for better use of collective action theory in research and governance for invasive species management. Conservation Biology 33(2):275-287. https://doi.org/10.1111/cobi.13266

Graham, S., and S. Rogers. 2017. How local landholder groups collectively manage weeds in south-eastern Australia. Environmental Management 60(3):396-408. https://doi.org/10.1007/ $\underline{\mathrm{s} 00267-017-0859-7}$

Hershdorfer, M. E., M. E. Fernandez-Gimenez, and L. D. Howery. 2007. Key attributes influence the performance of local weed management programs in the southwest United States. Rangeland Ecology and Management 60(3):225-234.

Janssen, M. A. 2013. The role of information in governing the commons: experimental results. Ecology and Society 18(4):4. https://doi.org/10.5751/ES-05664-180404

Klepeis, P., N. Gill, and L. Chisholm. 2009. Emerging amenity landscapes: invasive weeds and land subdivision in rural
Australia. Land Use Policy 26(2):380-392. https://doi. org/10.1016/j.landusepol.2008.04.006

Kollock, P. 1998. Social dilemmas: the anatomy of cooperation. Annual Review of Sociology 24:183-214. https://doi.org/10.1146/ annurev.soc.24.1.183

Lubell, M. 2002. Environmental activism as collective action. Environment and Behavior 34(4):431-454. https://doi. org/10.1177/00116502034004002

Lubell, M., A. Vedlitz, S. Zahran, and L. T. Alston. 2006. Collective action, environmental activism, and air quality policy. Political Research Quarterly 59(1):149-160. https://doi. org/10.1177/106591290605900113

Lubell, M., S. Zahran, and A. Vedlitz. 2007. Collective action and citizen responses to global warming. Political Behavior 29 (3):391-413. https://doi.org/10.1007/s11109-006-9025-2

Marshall, G. R. 2009. Polycentricity, reciprocity, and farmer adoption of conservation practices under community-based governance. Ecological Economics 68(5):1507-1520. https://doi. org/10.1016/j.ecolecon.2008.10.008

Marshall, G. R., M. J. Coleman, B. M. Sindel, I. J. Reeve, and P. J. Berney. 2016. Collective action in invasive species control, and prospects for community-based governance: the case of serrated tussock (Nassella trichotoma) in New South Wales, Australia. Land Use Policy 56:100-111. https://doi.org/10.1016/j.

landusepol.2016.04.028

Marshall, N. A., M. Friedel, R. D. van Klinken, and A. C. Grice. 2011. Considering the social dimension of invasive species: the case of buffel grass. Environmental Science and Policy 14 (3):327-338. https://doi.org/10.1016/j.envsci.2010.10.005

McKenzie-Mohr, D. 2011. Fostering sustainable behavior: an introduction to community-based social marketing. New Society, Gabriola Island, British Columbia, Canada.

McKenzie-Mohr, D., N. R. Lee, P. Wesley Schultz, and P. Kotler. 2012. Social marketing to protect the environment: what works. SAGE, Thousand Oaks, California, USA. https://doi. org/10.4135/9781483349466

McKiernan, S. 2017. Managing invasive plants in a rural-amenity landscape: the role of social capital and landcare. Journal of Environmental Planning and Management 61(8):1419-1437. https://doi.org/10.1080/09640568.2017.1351930

Merry, S. E. 1984. Rethinking gossip and scandal. Pages 271-302 in D. Black, editor. Toward a general theory of social control. Academic, Orlando, Florida, USA.

Milinski, M., D. Semmann, and H. J. Krambeck. 2002. Reputation helps solve the 'tragedy of the commons.' Nature 415 (6870):424-426. https://doi.org/10.1038/415424a

Minato, W., A. Curtis, and C. Allan. 2010. Social norms and natural resource management in a changing rural community. Journal of Environmental Policy and Planning 12(4):381-403. https://doi.org/10.1080/1523908X.2010.531084

Montana Department of Agriculture. 2017. Montana noxious weed list. Montana Department of Agriculture, Helena, Montana, USA. [online] URL: https://agr.mt.gov/Portals/168/ Documents/Weeds/2017\%20Noxious\%20Weed \%20List.pdf 
Nackley, L. L., A. G. West, A. L. Skowno, and W. J. Bond. 2017. The nebulous ecology of native invasions. Trends in Ecology and Evolution 32(11):814-824. https://doi.org/10.1016/j.tree.2017.08.003

Niemiec, R. M., N. M. Ardoin, C. B. Wharton, and G. P. Asner. 2016. Motivating residents to combat invasive species on private lands: social norms and community reciprocity. Ecology and Society 21(2):30. https://doi.org/10.5751/ES-08362-210230

Nowak, M. A., and K. Sigmund. 2005. Evolution of indirect reciprocity. Nature 437(7063):1291-1298. https://doi.org/10.1038/ nature 04131

Odum, W. E. 1982. Environmental degradation and the tyranny of small decisions. BioScience 32(9):728-729. https://doi. org/10.2307/1308718

Ostrom, E. 1990. Governing the commons. Cambridge University Press, New York, New York, USA.

Ostrom, E. 2000. Collective action and the evolution of social norms. Journal of Economic Perspectives 14(3):137-158. https:// doi.org/10.1257/jep.14.3.137

Panchanathan, K., and R. Boyd. 2004. Indirect reciprocity can stabilize cooperation without the second-order free rider problem. Nature 432(7016):499-502. https://doi.org/10.1038/nature02978

Parker, I. M., D. Simberloff, W. M. Lonsdale, K. Goodell, M. Wonham, P. M. Kareiva, M. H. Williamson, B. Von Holle, P. B. Moyle, J. E. Byers, and L. Goldwasser. 1999. Impact: toward a framework for understanding the ecological effects of invaders. Biological invasions 1(1):3-19. https://doi.org/10.1023/a:1010034312781

Reid, M., L. Coulston, B. Furze, D. Parker, P. Grey, and M. Mead. 2009. Blackberry control is more than science: understanding community engagement in pest management. Pages 77-81 in, Proceedings of the Fourth Victorian Weeds Conference - plants behaving badly: in agriculture and environment. Greelong, Australia.

Schelling, T. C. 1971. Dynamic models of segregation. Journal of Mathematical Sociology 1(2):143-186. https://doi.

org/10.1080/0022250X.1971.9989794

Selge, S., A. Fischer, and R. van der Wal. 2011. Public and professional views on invasive non-native species: a qualitative social scientific investigation. Biological Conservation 144 (12):3089-3097. https://doi.org/10.1016/j.biocon.2011.09.014

Selinske, M. J., B. Cooke, N. Torabi, M. J. Hardy, A. T. Knight, and S. A. Bekessy. 2016. Locating financial incentives among diverse motivations for long-term private land conservation. Ecology and Society 22(2):7. https://doi.org/10.5751/ES-09148-220207

Sheley, R., J. James, B. Smith, and E. Vasquez. 2010. Applying ecologically based invasive-plant management. Rangeland Ecology and Management 63(6):605-613. https://doi.org/10.2111/ REM-D-09-00187.1

Sheley, R. L., J. S. Jacobs, and J. W. Floyd. 1996. Noxious weed survey: awareness and attitudes in Montana. Weed Technology 10 (3):592-598. https://doi.org/10.1017/S0890037X00040495

Sheley, R. L., and B. S. Smith. 2012. Prioritizing invasive plant management strategies. Rangelands 34(6):11-14. https://doi. org/10.2111/rangelands-d-12-00064.1
Simberloff, D., J. L. Martin, P. Genovesi, V. Maris, D. A. Wardle, J. Aronson, F. Courchamp, B. Galil, E. García-Berthou, M. Pascal, P. Pyšek, R. Sousa, E. Tabacchi, and M. Vilà. 2013. Impacts of biological invasions: what's what and the way forward. Trends in Ecology and Evolution 28(1):58-66. https://doi. org/10.1016/j.tree.2012.07.013

Steele, J., R. S. Chandran, W. N. Grafton, C. D. Huebner, and D. W. McGill. 2006. Awareness and management of invasive plants among West Virginia woodland owners. Journal of Forestry 104 (5):248-253.

Urgenson, L. S., H. E. Prozesky, and K. J. Esler. 2013. Stakeholder perceptions of an ecosystem services approach to clearing invasive alien plants on private land. Ecology and Society 18(1):26. https:// doi.org/10.5751/ES-05259-180126

Vaske, J. J. 2008. Survey research and analysis: applications in parks, recreation, and human dimensions. Venture, State College, Pennsylvania, USA.

Yau, Y. 2011. Collectivism and activism in housing management in Hong Kong. Habitat International 35(2):327-334. https://doi. org/10.1016/j.habitatint.2010.11.006

Yung, L., and J. M. Belsky. 2007. Private property rights and community goods: negotiating landowner cooperation amid changing ownership on the Rocky Mountain Front. Society and Natural Resources 20(8):689-703. https://doi.org/10.1080/08941$\underline{920701216586}$

Yung, L., J. Chandler, and M. Haverhals. 2015. Effective weed management, collective action, and landownership change in western Montana. Invasive Plant Science and Management 8 (2):193-202. https://doi.org/10.1614/IPSM-D-14-00059.1

Zimdahl, R. L. 2018. Fundamentals of weed science. Academic, Orlando, Florida, USA. 
April 4, 2017

\section{Dear Montana Landowner:}

Last month we mailed you a survey about natural resource management on your property. You are one of a few Montana private landowners selected to participate in this study and your response will help natural resource management agencies across the state better design outreach programs for private landowners in Montana.

If you have already completed and returned this survey to us, please accept our sincere thanks. If not, please take some time to complete the survey and return it to us in the postage-paid envelope provided.

This survey asks about land management decisions relating to wildfire risk reduction, weed control and human-bear conflict reduction on private lands. In Montana, these three issues cross property boundaries and affect multiple landowners. Because these issues are widespread your input is valuable.

Your participation in this survey is completely voluntary and you may stop at any time or skip any question you do not wish to answer. All your answers will be anonymous - we will only report summaries of our findings. The identification number on the survey is there so we can check your name off the mailing list and save postage on future mailings.

It should take about 15-20 minutes to complete the survey. By completing and returning the questionnaire, you imply your consent to participate in this study. If you have any questions, do not hesitate to contact us.

Sincerely,

$$
\text { To complete the survey online! Go to: }
$$

Dr. Alexander L. Metcalf

Natural Resource Working Group

W. A. Franke College of Forestry and Conservation

alex.metcalf@umontana.edu

(406) 243-6673 


\section{Natural Resource Stewardship Survey A survey to support Montana's private landowners}

This survey has 4 sections with questions about your property, your interactions with people in your area, and your approach to three natural resource issues: wildfire, weeds, and human-bear conflict. We'd like to start by asking about your property and your reasons for owning.

1. Do you own more than 0.5 acres anywhere in the state of Montana? $\square$ Yes $\square$ No If no, please check the box and return the survey to us in the postage-paid envelope provided.

2. About how many total acres do you own in Montana? (acres)

3. The following are some reasons why people own land. When you think about why you own your land, how important is each of the following reasons? Please use the 1 to 5 scale, where 1 is "Very Unimportant" and 5 is "Very Important."

(For each row, please circle only one number.)

\begin{tabular}{|lccccc|}
\hline & $\begin{array}{c}\text { Very } \\
\text { Unimportant }\end{array}$ & Unimportant & Neither & Important & $\begin{array}{c}\text { Very } \\
\text { Important }\end{array}$ \\
\hline $\begin{array}{l}\text { Land investment (I hope to sell all or part } \\
\text { of my land for a profit) }\end{array}$ & 1 & 2 & 3 & 4 & 5 \\
\hline Personal use or recreation & 1 & 2 & 3 & 4 & 5 \\
$\begin{array}{l}\text { General income (e.g., sale of timber, } \\
\text { crops, cattle, leasing) }\end{array}$ & 1 & 2 & 3 & 4 & 5 \\
Solitude & 1 & 2 & 3 & 4 & 5 \\
Primary residence & 1 & 2 & 3 & 4 & 5 \\
\hline To pass on to family members & 1 & 2 & 3 & 4 & 5 \\
Rural lifestyle & 1 & 2 & 3 & 4 & 5 \\
\hline
\end{tabular}


4. In your own words, please describe why you own your property. 


\section{SECTION II - INVASIVE WEEDS}

Weeds are any non-native, undesirable plant species. The following questions ask about weeds on your property and the actions that some landowners take to control weeds.

\section{Weed Control on Your Property}

12. How strongly do you agree or disagree with the following statements? Please use the 1 to 5 scale, where 1 is "Strongly Disagree" and 5 is "Strongly Agree." (For each row, please circle only one number.)

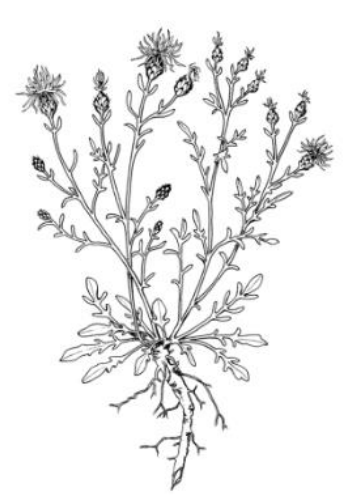

\begin{tabular}{|lccccc|}
\hline & $\begin{array}{c}\text { Strongly } \\
\text { Disagree }\end{array}$ & Disagree & Neither & Agree & $\begin{array}{l}\text { Strongly } \\
\text { Agree }\end{array}$ \\
\hline Weeds decrease my enjoyment of my property & 1 & 2 & 3 & 4 & 5 \\
Weeds decrease the economic value of my property & 1 & 2 & 3 & 4 & 5 \\
Weeds decrease the productivity of my property & 1 & 2 & 3 & 4 & 5 \\
$\begin{array}{l}\text { Weeds negatively impact the appearance of my } \\
\text { property }\end{array}$ & 1 & 2 & 3 & 4 & 5 \\
$\begin{array}{l}\text { Weeds limit my ability to use my property in the } \\
\text { ways I want }\end{array}$ & 1 & 2 & 3 & 4 & 5 \\
\hline
\end{tabular}

13. In your own words, please describe how weeds affect your ability to use your property in the ways you want, if applicable.

\section{Weed Control Activities}

14. How often do you take the following actions?

(For each row, please check only one box.)

\begin{tabular}{|l|c|c|c|}
\hline & Never & Sometimes & Always \\
\hline Wash your personal gear/clothing after being in an area with weeds & $\square$ & $\square$ & $\square$ \\
\hline Wash your vehicle after being in an area with weeds & $\square$ & $\square$ & $\square$ \\
\hline
\end{tabular}




\begin{tabular}{|l|c|c|c|}
\hline Buy weed-free alternatives (weed free forage, weed free gravel) & $\square$ & $\square$ & $\square$ \\
\hline Check your property for weeds & $\square$ & $\square$ & $\square$ \\
\hline
\end{tabular}

15. How strongly do you agree or disagree with the following statements? Please use the 1 to 5 scale, where 1 is "Strongly Disagree" and 5 is "Strongly Agree."

(For each row, please circle only one number.)

\begin{tabular}{|c|c|c|c|c|c|}
\hline & $\begin{array}{l}\text { Strongly } \\
\text { Disagree }\end{array}$ & Disagree & Neither & Agree & $\begin{array}{l}\text { Strongly } \\
\text { Agree }\end{array}$ \\
\hline $\begin{array}{l}\text { I have enough money to control weeds on my } \\
\text { property }\end{array}$ & 1 & 2 & 3 & 4 & 5 \\
\hline $\begin{array}{l}\text { I have enough time to control weeds on my } \\
\text { property }\end{array}$ & 1 & 2 & 3 & 4 & 5 \\
\hline I am confident in my ability to identify weeds & 1 & 2 & 3 & 4 & 5 \\
\hline $\begin{array}{l}\text { I am confident I know how to effectively control } \\
\text { weeds on my property }\end{array}$ & 1 & 2 & 3 & 4 & 5 \\
\hline $\begin{array}{l}\text { My personal actions can help control weeds on my } \\
\text { property }\end{array}$ & 1 & 2 & 3 & 4 & 5 \\
\hline
\end{tabular}

16. Have you ever spoken with a weed professional (commercial applicator, MSU extension agent) or received educational material about controlling weeds? $\square$ Yes $\square$ No If yes, who or what was most helpful?

\section{Weed Control in Your Area}

17. How strongly do you agree or disagree with the following statements? Please use the 1 to 5 scale, where 1 is "Strongly Disagree" and 5 is "Strongly Agree."

(For each row, please circle only one number.)

\begin{tabular}{|lll}
\hline Strongly & Disagree & Neither Agree $\begin{array}{c}\text { Strongly } \\
\text { Agree }\end{array}$
\end{tabular}




\begin{tabular}{|c|c|c|c|c|c|}
\hline $\begin{array}{l}\text { If you take actions to control weeds, neighboring } \\
\text { property owners will notice or hear about it }\end{array}$ & 1 & 2 & 3 & 4 & 5 \\
\hline $\begin{array}{l}\text { If you take actions to reduce the spread of weeds, it } \\
\text { will motivate neighboring property owners to take } \\
\text { similar actions }\end{array}$ & 1 & 2 & 3 & 4 & 5 \\
\hline $\begin{array}{l}\text { If neighboring property owners take actions to } \\
\text { reduce the spread of weeds, it will reduce the } \\
\text { amount of weeds on my property as well }\end{array}$ & 1 & 2 & 3 & 4 & 5 \\
\hline $\begin{array}{l}\text { Together, neighboring property owners and I can } \\
\text { effectively control weeds in our area }\end{array}$ & 1 & 2 & 3 & 4 & 5 \\
\hline
\end{tabular}

18. How satisfied or dissatisfied are you with the current efforts to control weeds in your area? (Please circle only one response.)

\begin{tabular}{|ccccc|}
\hline Very Dissatisfied & Dissatisfied & Neither & Satisfied & Very Satisfied \\
1 & 2 & 3 & 4 & 5 \\
\hline
\end{tabular}

19. Please answer the following "Yes" or "No" questions.

(For each row, please check only one box.)

\begin{tabular}{|c|c|c|c|}
\hline & Yes & No & $\begin{array}{c}\text { Do } \\
\text { Not } \\
\text { Know }\end{array}$ \\
\hline Has anyone ever asked you for your opinion on weed control? & $\square$ & $\square$ & \\
\hline Has anyone ever tried to influence your opinion on weed control? & $\square$ & $\square$ & \\
\hline $\begin{array}{l}\text { Do most people in your area believe you should be taking steps to control weeds on your } \\
\text { property? }\end{array}$ & $\square$ & $\square$ & $\square$ \\
\hline $\begin{array}{l}\text { Do you believe most people in your area are taking actions to control weeds on their } \\
\text { properties? }\end{array}$ & $\square$ & $\square$ & $\square$ \\
\hline
\end{tabular}




\section{SECTION IV - GENERAL QUESTIONS}

The following questions ask about general activities, interactions with people in your area, opinions across several natural resource topics, and a few questions about your household.

27. How willing or unwilling are you to do the following activities? Please use the 1 to 5 scale, where 1 is "Very Unwilling" and 5 is "Very Willing."

(For each row, please circle only one number.)

\begin{tabular}{|c|c|c|c|c|c|}
\hline & $\begin{array}{c}\text { Very } \\
\text { Unwilling }\end{array}$ & Unwilling & Neither & Willing & $\begin{array}{l}\text { Very } \\
\text { Willing }\end{array}$ \\
\hline Cut trees on your property & 1 & 2 & 3 & 4 & 5 \\
\hline $\begin{array}{l}\text { Contact your local fire department or other expert } \\
\text { to request a wildfire home assessment }\end{array}$ & 1 & 2 & 3 & 4 & 5 \\
\hline $\begin{array}{l}\text { Work with an extension professional to develop a } \\
\text { weed control plan for your property }\end{array}$ & 1 & 2 & 3 & 4 & 5 \\
\hline Use herbicides to control weeds & 1 & 2 & 3 & 4 & 5 \\
\hline Release bio-control (insects) to control weeds & 1 & 2 & 3 & 4 & 5 \\
\hline Spend time pulling weeds from your property & 1 & 2 & 3 & 4 & 5 \\
\hline Spend time pulling weeds along trails on public land & 1 & 2 & 3 & 4 & 5 \\
\hline $\begin{array}{l}\text { Apply for a government grant program to assist } \\
\text { with management costs }\end{array}$ & 1 & 2 & 3 & 4 & 5 \\
\hline $\begin{array}{l}\text { Cooperate with your neighbors to conduct } \\
\text { management }\end{array}$ & 1 & 2 & 3 & 4 & 5 \\
\hline $\begin{array}{l}\text { Work with a financial professional to establish an } \\
\text { estate plan }\end{array}$ & 1 & 2 & 3 & 4 & 5 \\
\hline Discuss your estate planning with your heirs/family & 1 & 2 & 3 & 4 & 5 \\
\hline
\end{tabular}

28. How strongly do you agree or disagree with the following statements? Please use the 1 to 5 scale, where 1 is "Strongly Disagree" and 5 is "Strongly Agree."

(For each row, please circle only one number.)

$\begin{array}{lll}\begin{array}{c}\text { Strongly } \\ \text { Disagree }\end{array} & \text { Disagree Neither Agree } & \begin{array}{c}\text { Strongly } \\ \text { Agree }\end{array}\end{array}$




\begin{tabular}{|lccccc|}
\hline $\begin{array}{l}\text { I feel a strong sense of community with my } \\
\text { neighbors }\end{array}$ & 1 & 2 & 3 & 4 & 5 \\
$\begin{array}{l}\text { If there is a problem in my area, people here get it } \\
\text { solved }\end{array}$ & 1 & 2 & 3 & 4 & 5 \\
$\begin{array}{l}\text { I have an influence over what this community is } \\
\text { like }\end{array}$ & 1 & 2 & 3 & 4 & 5 \\
$\begin{array}{l}\text { I often take an active role in solving area problems } \\
\text { of }\end{array}$ & 1 & 2 & 3 & 4 & 5 \\
\hline
\end{tabular}

29. What groups in your area do you associate with or feel most welcomed by (neighborhood, church group, garden club, rotary, $4 \mathrm{H})$ ?

30. How likely or unlikely are you to use the following sources when you need information about how to manage or do something on your property. Please use the 1 to 5 scale, where 1 is "Very Unlikely" and 5 is "Very Likely."

(For each row, please circle only one number.)

\begin{tabular}{|lccccc|}
\hline & $\begin{array}{c}\text { Very } \\
\text { Unlikely }\end{array}$ & Unlikely & Neither & Likely & $\begin{array}{c}\text { Very } \\
\text { Likely }\end{array}$ \\
\hline General internet search & 1 & 2 & 3 & 4 & 5 \\
Other landowners & 1 & 2 & 3 & 4 & 5 \\
MSU extension office & 1 & 2 & 3 & 4 & 5 \\
Weed district & 1 & 2 & 3 & 4 & 5 \\
State government (MT DNRC, Fish, Wildlife, \& Parks) & 1 & 2 & 3 & 4 & 5 \\
$\begin{array}{l}\text { Federal government (Forest Service; Bureau of Land } \\
\text { Management) }\end{array}$ & 1 & 2 & 3 & 4 & 5 \\
Family or friends & 1 & 2 & 3 & 4 & 5 \\
Local businesses & 1 & 2 & 3 & 4 & 5 \\
\hline Professional advisor/consultant & 1 & 2 & 3 & 4 & 5
\end{tabular}




\begin{tabular}{|lccccc|} 
Neighborhood network & 1 & 2 & 3 & 4 & 5 \\
Community wildfire preparedness group & 1 & 2 & 3 & 4 & 5 \\
Workshops or classes & 1 & 2 & 3 & 4 & 5 \\
Brochures or other printed material & 1 & 2 & 3 & 4 & 5 \\
\hline
\end{tabular}

31. How strongly do you agree or disagree with the following statements? Please use the 1 to 5 scale, where 1 is "Strongly Disagree" and 5 is "Strongly Agree."

(For each row, please circle only one number.)

\begin{tabular}{|c|c|c|c|c|c|}
\hline & $\begin{array}{l}\text { Strongly } \\
\text { Disagree }\end{array}$ & Disagree & Neither & Agree & $\begin{array}{l}\text { Strongly } \\
\text { Agree }\end{array}$ \\
\hline $\begin{array}{l}\text { Economic growth should be given priority, even if the } \\
\text { environment suffers }\end{array}$ & 1 & 2 & 3 & 4 & 5 \\
\hline The balance of nature is delicate and easily upset & 1 & 2 & 3 & 4 & 5 \\
\hline $\begin{array}{l}\text { I see my land as self-contained - I don't think much } \\
\text { about the surrounding land }\end{array}$ & 1 & 2 & 3 & 4 & 5 \\
\hline I trust the government to manage wildfire risk & 1 & 2 & 3 & 4 & 5 \\
\hline I trust the government to control weeds & 1 & 2 & 3 & 4 & 5 \\
\hline $\begin{array}{l}\text { I trust the government to reduce human-bear } \\
\text { conflict }\end{array}$ & 1 & 2 & 3 & 4 & 5 \\
\hline
\end{tabular}

32. How many children and/or dependents do you have living at home?

33. Do you plan to leave your land to any heirs (e.g., children, dependents, relatives)?
$\square$ No $\square$ Yes If yes, how many? (number of heirs)

34. What is the highest grade of school you completed? (Please check only one box.) $\square$ Grade school $\square$ High school/GED $\square$ some college $\square$ College graduate $\square$ post graduate

35. What is your gender? $\square$ Male $\square$ Female $\square$ Prefer not to answer

36. What year were you born? (year) 
37. How long have you owned your property in Montana?

(years)

38. What is your approximate annual household income before taxes (optional)?

(Please check only one box.)

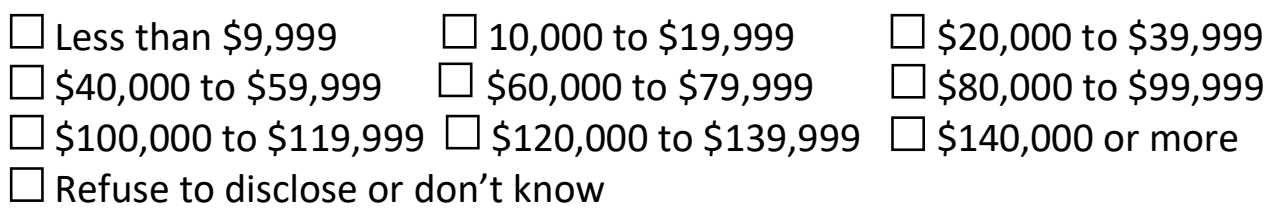

Thank you for taking this survey. If you have any comments, please include them in the space below: 